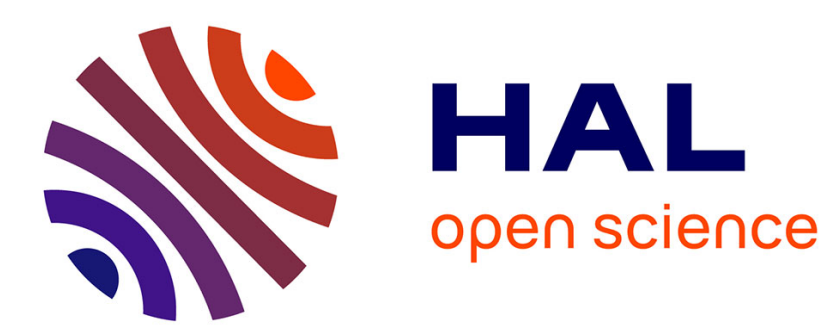

\title{
Book Review: Utopia and Organization
}

Joseph F. Patrouch

\section{To cite this version:}

Joseph F. Patrouch. Book Review: Utopia and Organization. European Journal of Cultural Studies, 2006, 9 (2), pp.245-248. 10.1177/136754940600900208 . hal-00571493

\section{HAL Id: hal-00571493 \\ https://hal.science/hal-00571493}

Submitted on 1 Mar 2011

HAL is a multi-disciplinary open access archive for the deposit and dissemination of scientific research documents, whether they are published or not. The documents may come from teaching and research institutions in France or abroad, or from public or private research centers.
L'archive ouverte pluridisciplinaire HAL, est destinée au dépôt et à la diffusion de documents scientifiques de niveau recherche, publiés ou non, émanant des établissements d'enseignement et de recherche français ou étrangers, des laboratoires publics ou privés. 
parkland. David Crowley's chapter explores the 'ambiguity' (p. 184) of the 'private' socialist home in Warsaw, focusing on tensions in the design and construction of residential apartments between creating them to be convenient physical dwellings and as 'representations of ideal spaces'. In the initial phase of urban residential construction, priority was given to the latter consideration, which produced an over-emphasis on the monumental external form of buildings, designed to fit into planned urban vistas and 'publicizing' the private just as articles in popular women's magazines stressed the role of the home as a 'site of production' (p. 190) of commodities and good character. Only from the mid-1950s did architects and designers begin to create spaces which offered scope for the individual creativity of residents, potential for the 'personalization' of the domestic and the assertion of 'personality'. Remaining indoors, Katerina Gerasimova's chapter considers the relationship between public and private space in the Soviet communal flat, addressing issues of social control, the normalization of behaviour and strategies of individual resistance in an environment of 'public privacy' (p. 224). The final chapter by Mark Allen Svede tells the intriguing story of how a Latvian proposal for the Soviet pavilion at Expo 92 in Seville first won the commission, was then disqualified on spurious grounds and finally reinstated, thanks to the fact that the jury of distinguished Soviet architects failed to recognize the cunning and subversive symbolism incorporated into the model. By the time Expo 92 opened, the Russian pavilion realized all the mischievous intentions of its Latvian designers: it stood as a 'dysfunctional mausoleum' of Russia's socialist heritage, ugly, bedecked with broken-down technology and relegated to a peripheral site on the world's stage.

All the contributions to this volume represent useful contributions to the growing body of literature on the politics of space, material culture, urban planning and everyday life, as well as offering engrossing insights into East-European social history and some valuable ways of conceptualizing social reality and practice. As such, it will be of great interest not only to East European area studies specialists, but also to cultural and social historians and to practitioners in the field of urban planning and architecture.

Nick Baron

University of Nottingham

Martin Parker (ed.), Utopia and Organization. Oxford: Blackwell, 2002. 233 pp. (inc. index). ISBN 1-4051-0072-9

Martin Parker, recent author of Against Management: Organization in the Age of Managerialism (Polity Press, 2002) and Science Fiction and Organization (Routledge, 2001), among other works on the topics of 
organizational behaviour and management, and reader in social and organizational theory in the Department of Management at the University of Keele, has assembled 10 articles written by colleagues at Keele and other British universities. (In addition, one contributor is from Sweden and one a coffee house owner in Arizona. As editor of the series, Parker has chosen to organize a 'kind of sequel' to his earlier collection Ethics and Organizations [1998] [p. 223, Note 5].)

The earlier work, 14 revised papers from a 1997 workshop, included articles by three of the authors whose work also appears in the book currently under review (Parker, Roland Munro and Hugh Willmott). The more recent work continues discussion of a variety of themes relating to ethics and, as Parker describes it in his final contribution, "impatience with the present' as marked by the 'hegemonic ideology of market managerialism' (p. 223). He continues: 'it still seems to me that there are many different ways of thinking about how human beings might organize themselves' (p. 223). What better place to connect with than ideas about utopia?

The shadows of aircraft destroying skyscrapers linger in the texts of a number of the contributions to this volume (and one entire article by John Law and Annemarie Mol is dedicated to the management of trainwrecks); the quiet pleasures of Arcadia seem appealing to thinkers caught in the maelstrom of the present. Much like the early 16th century, when Thomas More coined the term 'utopia', people were and are rethinking categories of organization and wondering if the ones that had brought them to where they were would be the appropriate ones to take them where they wanted to go. In More's England, the royal authorities would succeed in wresting away morality and its regulation from the ecclesiastical specialists to whom such spheres had been granted previously, and the long march to the unitary secular administration and organization of the present was well on its way.

Now that the bloodied beanbag projectiles have been swept up and the truncheons stowed in the aftermath of the tense FTAA meetings here in Miami, a discussion of a book about utopias seems particularly striking. As Gibson Burrell and Karen Dale point out in their fascinating discussion 'Utopiary: Utopias, Gardens and Organization', Florida has seen more than its share of managed futures and 'communities of tomorrow'. As Burrell and Dale write, 'it appears to be Florida where utopian plans for the new cities ... are being concretized' (p. 117). And not only in the gardens of Disney's realm. (For a brief discussion of Disney and utopia, see Bryman, 1995: 140-2.) Burrell and Dale successfully tie discussions of landscape architecture in the European past, particularly in its Baroque manifestations in the centuries following More, to a certain 'madness of order' with contemporary echoes that recall the works of Kafka, Orwell and Huxley (p. 125). Roland Munro similarly uses the example of the garden, and a particular English park and house over time, to relate issues tied to the consumption of time and space. By concentrating on a nearby place, he 
succeeds in dealing with how, as he puts it, 'Utopia has a far-off feel' (p. 128).

Various of the other authors in this collection also choose to craft their discussions of utopia(s) by reference to the European pasts (with which, by virtue of their insular/British location, they are theoretically acquainted and by which they are theoretically influenced). Roy Stager Jacques, for example, traces the transformation of English Puritanism in the New England and New York contexts. He argues that a 'crypto-utopian transformation' which is 'materially connected to commerce' is connected to how 'Calvinist salvation is no longer achieved through good works, but through the quantity of work, whatever its quality' (pp. 32-3; emphases in original). Discussing Mannheim's influential concepts tied to utopia, Stephen Ackroyd points out not only that Mannheim was a refugee from a disintegrated empire, but that Mannheim saw the limits to utopianism partly due to his interpretation, which gave substantial roles to radical Christian movements such as the Anabaptists, movements that were generally short-lived and unsuccessful (p. 51).

For Martin Parker, utopianism 'is a systematic investigation of alternative principles of organization' (p. 217). Both Patrick Reedy and Valerie Fournier in their contributions to the volume place the study of utopia and organization squarely next to contemporary concerns. Pointing to the anti-capitalist and environmental protests of recent times, Reedy underlines the positive sides of 'anarchist utopianism', which 'can be powerfully nostalgic, frequently displaying a longing for a past that never was but that should have been' (p. 170). He even goes so far as to assert that 'the genre of utopianism may provide an escape from the sometimes stultifying cul-de-sac of academic writing' (p. 186). Fournier emphasizes the potential to open up 'conceptual space within which alternatives can be imagined' by 'making the "normal", the currently possible, look strange, absurd, grotesque' (p. 194), while realizing 'that we cannot know for sure that alternatives will be better, we can only hope, take the risk. Utopianism is about grabbing these moments of hope and risk and running with them, it is about embracing undecidability, and the choices and responsibilities that go with it' (pp. 200-1).

As could be expected from such a collection, the approaches, tones and styles of the various chapters vary tremendously, as does the type of evidence adduced. What brings them all together is a sense that somehow there must be (is?) another way or set of ways to imagine social organization, ones different from those of the managers (the palm readers of the hidden hands of the market, as Parker describes them on p. 3) whose words stare out from airport bookstalls around the world (p. 5). Is this sense too utopian? 


\section{Reference}

Bryman, Alan (1995) Disney and His Worlds. London: Routledge.

Joseph F. Patrouch

Florida International University

Jan Wieten, Graham Murdock and Peter Dahlgren (eds), Television Across Europe: A Comparative Introduction. London: Sage, 2000. 268 pp. (inc. index). ISBN 0-7619-6884-9 (hbk); ISBN 0-7619-6885-7 (pbk) $£ 18.99$

Television Across Europe, by January Wieten, Graham Murdock and Peter Dahlgren, tries to give a picture of the processes that influenced the development of television to become the dominant medium in Europe and which will become increasingly relevant for the near future. In so doing, television appears as a medium of symbolic representation and as an institution that depends on the structures of economy. Primarily, television makes public reflection possible and produces, slows down and yet accelerates social processes. It is this social and institutional framework of television with which the first part of the book concerns itself. The authors are concerned with the monopoly of public television and the division into public and private networks which took place in many European countries during the 1980s. Here, central topics include the consequences of political-economic deregulation, the fragmentation of viewers caused by the emergence of new channels, the influence of digital transmission methods and the increasing convergence of television, telecommunications and computers.

The publication's second section addresses current trends and patterns as well as the organization and financing of contemporary television programmes. The authors approach the question of whether the acceptance of imported content and commercial television formats has brought about an Americanization of European TV. Furthermore, different types of programme production are described. For example, private networks no longer mainly try to develop original programmes. Instead, they follow a strategy called 'programming': productions with the sole aim of selling viewer ratings to advertising companies.

On the basis of selected television genres and new 'hybrid' programme forms, the third section points out changes within the European television society and the complicated relation of the global and local. MTV's altered strategy of adapting musical, cultural and linguistic diversity in order to compete with local television stations may serve as an example here, as may the European acceptance of the American breakfast television format, a mix of information, service and entertainment linked by a strong involvement of viewers.

248 In their essays - all of which were produced in the context of the 